\title{
FASILITASI INKUBASI USAHA MANDIRI KECAMATAN LAKARSANTRI KOTA SURABAYA TAHUN 2018
}

\author{
Hendrik Rizqiawan ${ }^{1}$, Karlin $^{2}$, Andi Iswoyo ${ }^{3}$, Agung Bayu Murti ${ }^{4}$, Yanuar Fauzuddin ${ }^{5}$ \\ ${ }^{1}$ Universitas Wijaya Putra \\ ${ }^{2}$ Universitas Wijaya Putra \\ ${ }^{3}$ Universitas Wijaya Putra \\ ${ }^{4}$ Universitas Wijaya Putra \\ ${ }^{5}$ Universitas Wijaya Putra
}

hendrik_rizqiawan@yahoo.com, karlinantoni354@gmail.com, andi@uwp.ac.id, yanuarfauzuddin@gmail.com, abayum@gmail.com

\begin{abstract}
Abstrak
Jumlah penduduk Kota Surabaya per triwulan I tahun 2017 sebanyak 3.316.131 jiwa. Sebesar 18,59\% dari jumlah tersebut berstatus mengurus rumah tangga dan $24,44 \%$ nya belum bekerja. Jumlah penduduk miskin Kota Surabaya juga meningkat dari tahun 2014 ke tahun 2015. Hal tersebut menjadi pertimbangan utama bagi tim Dosen dari FEB UWP dan Pakar dari Lembaga Konsultan PT. Talenta Sukses Indonesia (PT. TSI) beserta perwakilan pemerintah kota melalui Dinas Pengendalian Penduduk, Pemberdayaan Perempuan dan Perlindungan Anak (DP5A) mengadakan program pendampingan usaha berupa fasilitasi inkubasi usaha mandiri. Program yang berjalan selama bulan April hingga Agustus tahun 2018 berlokasi di Kecamatan Lakarsantri Kota Surabaya ini mengkhususkan pelatihan dan pendampingan kepada para peserta dengan kriteria sebagai ibu rumah tangga dan memiliki tingkat ekonomi yang kurang mampu/miskin. Program pada khususnya bertujuan untuk memberdayakan penduduk yang merupakan ibu-ibu yang berstatus belum bekerja dan mengurus rumah tangga dengan kondisi perekonomian yang kurang mampu/miskin melalui kegiatan fasilitasi inkubasi usaha mandiri, sehingga mereka dapat lebih produktif dan mendapatkan tambahan penghasilan. Tujuan program pada umumnya, diharapkan dengan bertambahnya jumlah wirausaha baru dapat meningkatkan jumlah usaha mikro dan kecil pada Kota Surabaya, sehingga perekonomian Kota Surabaya dapat semakin tumbuh.
\end{abstract}

Kata Kunci : Pemberdayaan, Kewirausahaan, Mandiri, Surabaya

\section{PENDAHULUAN}

Kota Surabaya merupakan ibukota Provinsi Jawa Timur yang memiliki luas wilayah kurang lebih 326,36 km2 yang terbagi dalam 31 Kecamatan dan 154 Kelurahan. Jumlah penduduk Kota Surabaya sebagaimana yang terdata oleh Dinas
Kependudukan dan Catatan Sipil per triwulan I tahun 2017 adalah sebanyak 3.316.131 jiwa. Dari jumlah penduduk tersebut, $28,07 \%$ merupakan karyawan swasta, $17,73 \%$ merupakan pelajar/mahasiswa, $18,59 \%$ berstatus mengurus rumah tangga, $24,44 \%$ nya belum bekerja, dan sisanya memiliki pekerjaan yang beragam.

Ekonomi, Sosial, dan Budaya 
Dengan persentase yang terbilang masih cukup besar pada penduduk yang belum bekerja dan mengurus rumah tangga, tim Dosen dari FEB UWP dan Pakar dari Lembaga Konsultan PT. Talenta Sukses Indonesia (PT. TSI) beserta perwakilan pemerintah kota melalui Dinas Pengendalian Penduduk, Pemberdayaan Perempuan dan Perlindungan Anak (DP5A) merasa perlu diadakannya program pendampingan usaha pada mereka agar dapat lebih produktif. Hal tersebut juga sejalan dengan program pemerintah kota dalam mengurangi jumlah penduduk miskin di Kota Surabaya, karena jumlah penduduk miskin Kota Surabaya pada tahun 2015 bertambah dibandingkan tahun 2014 sebagaimana tergambar pada tabel 2 . Hal tersebut senada dengan penelitian yang dilakukan oleh Kurniawan dan Fauziah (2014) yang menyatakan bahwa pemberdayaan masyarakat melalui UMKM dapat membantu meningkatkan perekonomian masyarakat setempat yang masih tergolong miskin.

Tabel 1. Angka dan Garis Kemiskinan serta Jumlah Penduduk Miskin Kota Surabaya

\begin{tabular}{|l|c|c|}
\hline \multicolumn{1}{|c|}{ Kemiskinan } & $\mathbf{2 0 1 4}$ & $\mathbf{2 0 1 5}$ \\
\hline Angka Kemiskinan (persen) & 5,79 & 5,82 \\
\hline Garis Kemiskinan (Rp) & 393.151 & 418.93 \\
\hline Jumlah Penduduk Miskin (ribu jiwa) & 164,36 & 165,72 \\
\hline
\end{tabular}

BPS Kota Surabaya, 2017 dalam Rancangan Akhir RKPD Kota Surabaya Tahun 2018

Pendampingan usaha yang dimaksud adalah program pemberdayaan ekonomi melalui kegiatan fasilitasi inkubasi usaha mandiri bagi para peserta yang merupakan penduduk dengan kondisi perekonomian yang kurang mampu/miskin. Dengan adanya sebuah usaha yang dijalankan, para peserta dapat meningkatkan perekonomian mereka. Dan adapun wilayah yang akan menjadi objek fasilitasi inkubasi usaha mandiri ini adalah Kecamatan Lakarsantri Kota Surabaya wilayah barat. Pendampingan usaha ini juga diharapkan dapat sebagai solusi atas berkurangnya jumlah usaha mikro dan kecil di Kota Surabaya pada tahun 2016 dari dua tahun sebelumnya, seperti tersebutkan pada tabel di bawah ini. Tentunya semakin banyak usaha yang berada disebuah daerah dapat membantu dalam meningkatkan perekonomian daerah tersebut, seperti yang disampaikan oleh Nainggolan dkk (2017) bahwa perkembangan Usaha Mikro Kecil dan Menengah (UMKM) memilki peran yang sangat penting dalam pembangunan perekonomian daerah.

Tabel 2. Persentase Usaha Mikro dan Kecil Kota Surabaya

\begin{tabular}{|c|l|c|c|c|}
\hline No. & \multicolumn{1}{|c|}{ Uraian } & $\mathbf{2 0 1 4}$ & $\mathbf{2 0 1 5}$ & $\mathbf{2 0 1 6}$ \\
\hline 1 & Jumlah seluruh UMKM & 28.759 & 29.507 & 26.854 \\
\hline 2 & Jumlah Usaha Mikro dan Kecil & 26.037 & 26.800 & 22.924 \\
\hline 3 & $\begin{array}{l}\text { Persentase Usaha Mikro dan } \\
\text { Kecil }\end{array}$ & 90,54 & 90,83 & 85,37 \\
\hline
\end{tabular}

Dinas Penanaman Modal dan Pelayanan Terpadu Satu Pintu, Dinas Koperasi dan Usaha Mikro, 2017 dalam Rancangan Akhir RKPD Kota Surabaya Tahun 2018

Dari paparan di atas dapat dirumuskan tujuan dari program ini antara lain 1) Pemberdayaan ekonomi penduduk yang berstatus belum bekerja dan mengurus (ibu) rumah tangga dengan kondisi perekonomian yang kurang mampu melalui kegiatan fasilitasi inkubasi usaha mandiri, 2) Menambah penghasilan bagi objek sasaran program dan keluarga, 3) Meningkatkan jumlah usaha mikro dan kecil pada Kota Surabaya.

\section{METODE}

Program fasilitasi inkubasi usaha mandiri ini terdiri dari kegiatan beberapa pelatihan dan pendampingan - pendampingan. Tim memberikan sentuhan-sentuhan praktis yang diwujudkan dalam bentuk metode dan implementasi pemberdayaan ekonomi secara komprehensif, dengan perlakuan dari hulu hingga hilir, yaitu mulai dari program pemberian motivasi, pelatihan ketrampilan, pelatihan manajemen usaha, penyuluhan perijinan dan permodalan, pendampingan usaha hingga bantuan modal peralatan usaha. Adapun beberapa pelatihan yang akan diberikan kepada peserta terdapat tujuh jenis pelatihan yaitu :

1. Pelatihan Motivasi Wirausaha

2. Pelatihan Keterampilan Produksi

3. Pelatihan Manajemen Pemasaran

4. Pelatihan Manajemen Keuangan

5. Pelatihan Manajemen Organisasi dan SDM

6. Penyuluhan Legalitas dan Lingkungan Usaha

7. Penyuluhan Akses Permodalan

Setelah rangkaian pelatihan selesai kemudian dilanjutkan dengan pendampingan. Pendampingan ini memfasilitasi peserta agar dapat konsultasi terkait hasil mereka mempraktekkan ilmu yang sudah diberikan pada beberapa pelatihan sebelumnya. Disamping menerima konsultasi para

$$
\text { Ekonomi, Sosial, dan Budaya }
$$


narasumber pendampingan juga memberikan tips dan trik untuk mengatasi permasalahanpermasalahan yang dihadapi peserta. Adapun jenis pendampingan yaitu :

1. Pendampingan Ketrampilan Produksi

2. Pendampingan Manajemen Pemasaran

3. Pendampingan Manajemen Keuangan

4. Pendampingan Manajemen Organisasi dan SDM

5. Pendampingan Legalitas Usaha

\section{HASIL DAN PEMBAHASAN}

\section{Pelatihan dan Pendampingan Fasilitasi Inkubasi Usaha Mandiri}

Pelatihan dan pendampingan fasilitasi inkubasi usaha mandiri ini diadakan di Kantor Kelurahan Lidah Kulon Kecamatan Lakrsantri Kota Surabaya. Peserta Pelatihan adalah penduduk yang berstatus belum bekerja dan mengurus (ibu) rumah tangga dengan kondisi perekonomian yang kurang mampu, yang keseluruhannya adalah ibu-ibu (wanita). Peserta berjumlah 48 orang pada awal pelatihan, namun hingga akhir program bertahan hanya 16 orang yang dibagi menjadi 5 kelompok. Para peserta tersebut berasal dari 5 Kelurahan yang berada di Kecamatan Lakarsantri, yaitu Kelurahan Lakarsantri, Kelurahan Jeruk, Kelurahan Bangkingan, Kelurahan Lidah Kulon dan Kelurahan Lidah Wetan.

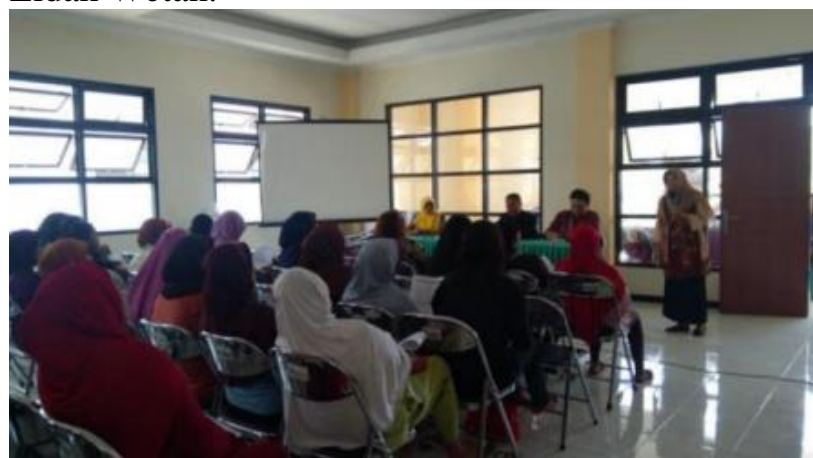

Gambar 1. Pembukaan Program Fasilitasi Inkubasi Usaha Mandiri yang dihadiri oleh Para Peserta, Tim Dosen dari FEB UWP, Pakar dari TSI, Perwakilan Pejabat Kecamatan Lakarsantri dan DP5A

\section{1 Pelatihan Motivasi Usaha}

Pelatihan motivasi usaha merupakan pelatihan yang bertujuan untuk menstimulus munculnya minat untuk berwirausaha. Pelatihan ini bertujuan untuk mengedukasi peserta agar memiliki pikiran lebih terbuka terhadap peluang-peluang meningkatkan penghasilan keluarga melalui berwirausaha. Sebagaimana yang dipaparkan oleh Umasugi (2012), bahwa diperlukan pelatihan yang bertujuan untuk mengubah pola pikir/paradigma sebeagai seorang wirausaha agar UKM menjadi kuat, tidak manja, kreatif, inisiatif dan produktif.

Selain penyampaian materi motivasi didukung juga oleh kesaksian (testimoni) dari pengusaha yang sudah sukses berwirausaha meskipun memulai usaha tanpa memiliki modal yang mencukupi dan akhirnya usahanya dapat berkembang dan sukses. Kesaksian (testimoni) Wirausaha Sukses disampaikan oleh Bu Sutinem yang merupakan pengusaha Makanan Ringan berbagai varian yang memulai usaha karena ingin meningkatkan perekonomian keluarga hanya bermodal sebuah singkong hasil minta kepada petani yang dijadikan modal untuk membuat kerupuk samiler.

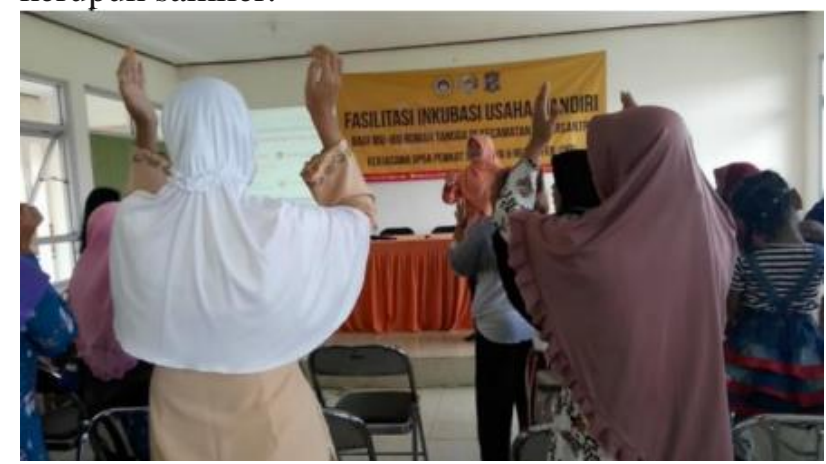

Gambar 2. Pelatihan Motivasi Usaha oleh Karlin, S.E., M.Ak.

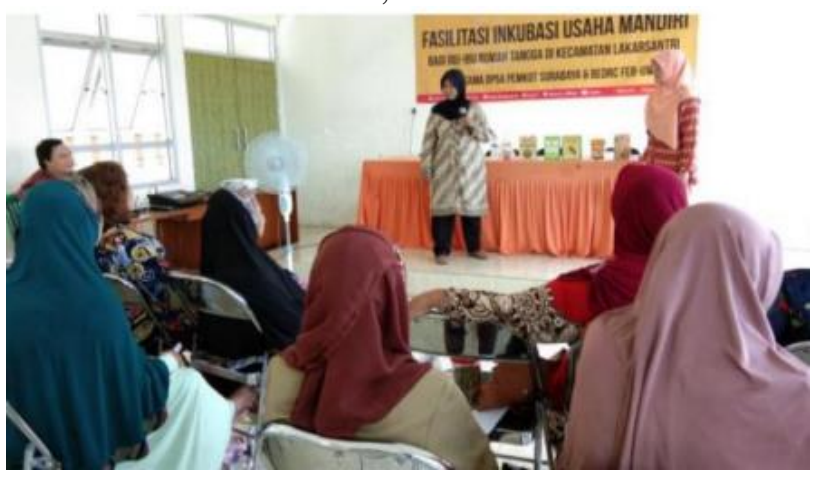

Gambar 3. Kesaksian (Testimoni) Pengusaha Sukses dari Ibu Sutinem

\section{2 Pelatihan Ketrampilan Produksi}

Pelatihan keterampilan produksi bertujuan agar peserta memiliki keterampilan untuk Ekonomi, Sosial, dan Budaya $\quad 1140$ 
memproduksi sebuah produk yang dapat dijadikan usaha mandiri. Pelatihan Keterampilan ini mengajarkan untuk memproduksi stick semanggi dimana salah satu bahan baku nya berupa sayur semanggi. Adanya kandungan sayur diharapkan memberi nilai tambah untuk produk yang dihasilkan oleh peserta. Pertimbangan yang lain adalah produk yang dilatihkan adalah produk yang mudah dan cepat diproduksi, biaya yang terjangkau dan cepat untuk dipasarkan sehingga cepat menghasilkan.

Nurjanah, dkk (2012) dalam risetnya yang berjudul "Aktivitas Antioksidan dan Komponen Bioaktif Semanggi Air (Marsilea Crenata)" menyebutkan bahwa ekstrak kasar metanol semanggi air memiliki aktivitas antioksidan yang tinggi dengan nilai IC50 sebesar 634,73 ppm, sehingga semanggi air dapat dikembangkan dalam industri pangan dan farmasi.

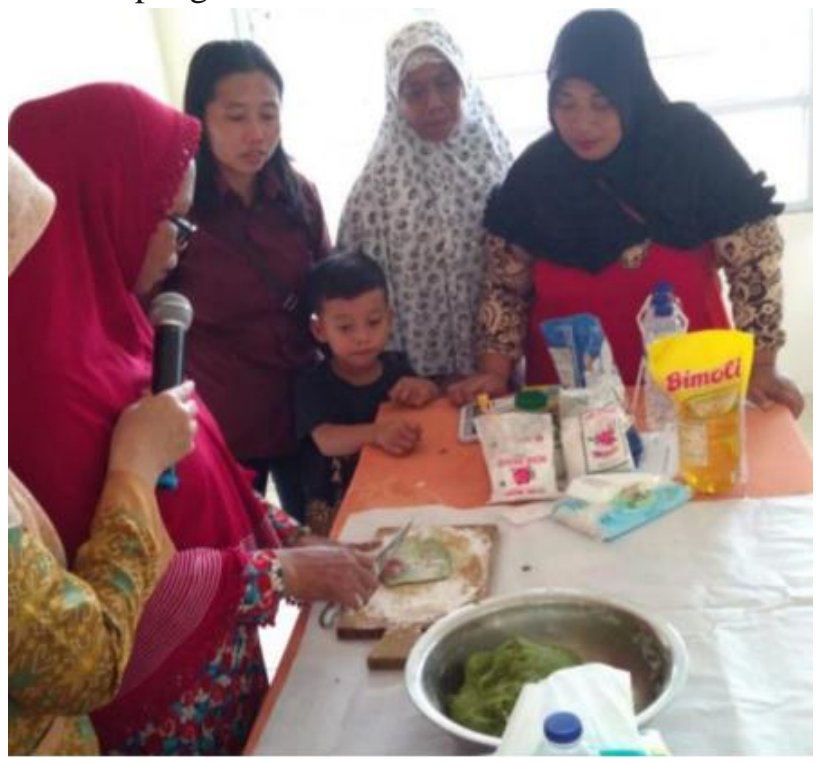

Gambar 4. Pelatihan Ketrampilan Produksi dari Ibu Sutinem

\section{3 Pelatihan Manajemen Pemasaran}

Pelatihan manajemen pemasaran dengan judul "Cara Memasarkan Produk Agar Laris Manis". Pelatihan Manajemen Pemasaran ini bertujuan untuk mengedukasi peserta pelatihan agar memahami cara melakukan pemasaran secara baik dan benar. Kemampuan untuk melakukan pemasaran merupakan salah satu bagian penting dalam wirausaha, karena strategi pemasaran yang tepat dapat meningkatkan daya saing sebuah usaha, khususnya bagi UMKM (Wibowo, 2015).

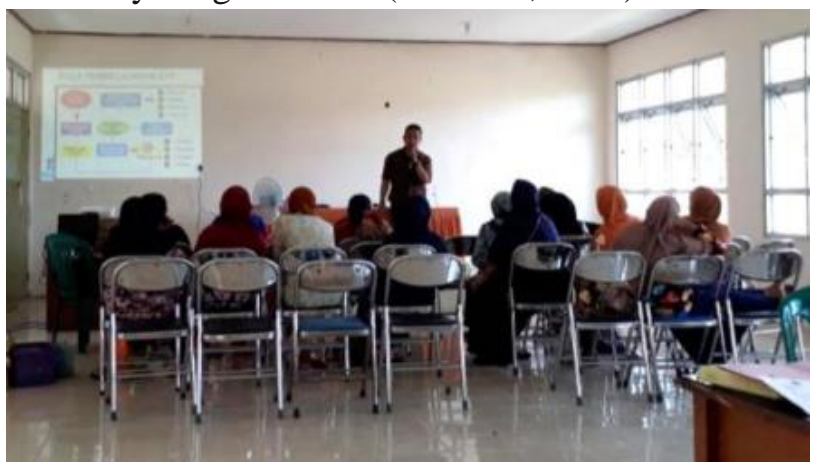

Gambar 5. Pelatihan Manajemen Pemasaran oleh Agung Bayu Murti, S.E, M.SE.

\section{4 Pelatihan Manajemen Keuangan}

Pelatihan manajemen keuangan dengan judul "Cara Menghitung Biaya, Menentukan Harga dan Menghindari Kerugian Usaha Agar Selalu Untung". Peserta mendapat pengetahuan dasar tentang manjemen keuangan sehingga peserta mampu menentukan harga jual produknya, mampu melakukan pencatatan sederhana dan dapat menghitung keuntungannya.

Menurut Kasmir dan Jakfar (2012:10), salah satu penyebab gagalnya seseorang dalam melakukan usaha adalah salah perhitungan. Hal tersebut dimungkinkan karena salah pengelolaan keuangan, sehingga dalam menjalankan sebuah usaha perlu pemahaman terkait manajemen keuangan yang tepat.

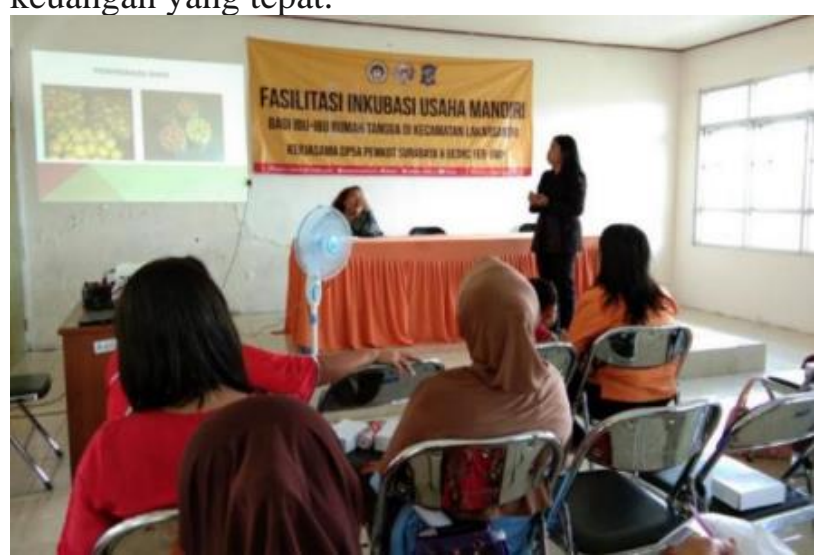

Gambar 6. Pelatihan Manajemen Keuangan oleh Aminatuzzuhro, S.E., M.Si.

\subsection{Pelatihan Manajemen Organisasi dan SDM} Ekonomi, Sosial, dan Budaya 
Pelatihan manajemen organisasi dan SDM dengan judul "Kerja Santai Berkualitas" merupakan pelatihan yang bertujuan agar peserta mampu membagi tugas anggota kelompok dan masingmasing mampu menjalankan tugasnya dengan baik tanpa merasa iri dengan anggota lain. Apabila omset terus meningkat dan mereka butuh untuk mempekerjakan orang lain untuk membantu produksi atau pemasaran, diharapkan mampu mengorganisir orang yang dipekerjakan tersebut dengan baik. Atmaja dan Ratnawati (2018) dalam penelitiannya menjelaskan bahwa peningkatan kualitas Manajemen SDM dan juga peran pemerintah diharapkan mampu meningkatkan pengetahuan dan ketrampilan pengusaha.

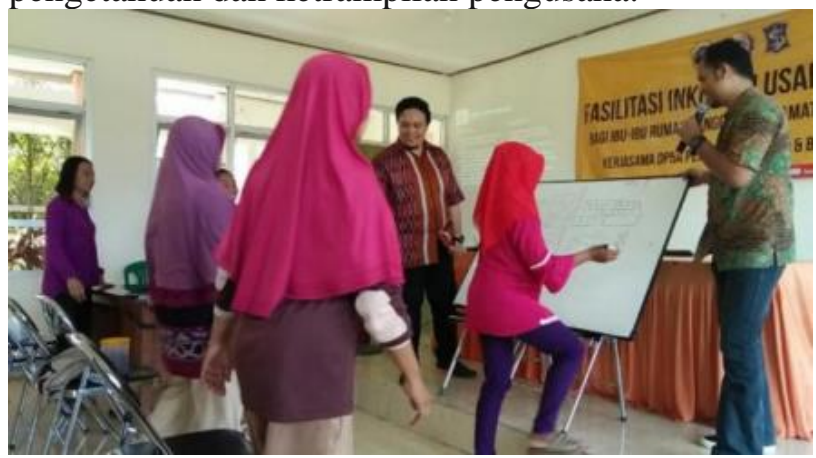

Gambar 7. Pelatihan Manajemen Organisasi dan SDM oleh Yanuar Fauzuddin, S.E, M.M.

\section{6 Penyuluhan Legalitas dan Lingkungan Usaha}

Penyuluhan legalitas merupakan edukasi bagi peserta untuk mengetahui cara mengurus perijinan atau legalitas bagi produk yang telah diproduksi oleh peserta pelatihan. Legalitas sangat penting untuk mengembangkan usaha agar tidak terkendala saat dipasarkan ke wilayah yang lebih luas. Legalitas suatu perusahaan atau badan usaha adalah merupakan unsur yang terpenting, karena legalitas merupakan jati diri yang melegalkan atau mengesahkan suatu badan usaha sehingga diakui oleh masyarakat (Fitriani, 2017).

Peserta juga diberikan pemahaman terkait pentingnya lingkungan yang bersih dan aman terutama pada saat proses produksi. Dapur kerapkali dijadikan tempat produksi. Dapur mempunyai peranan yang sangat penting dalam proses pengolahan makanan, karena itu kebersihan dapur dan lingkungan sekitarnya harus selalu terjaga dan diperhatikan (Atmoko, 2017).

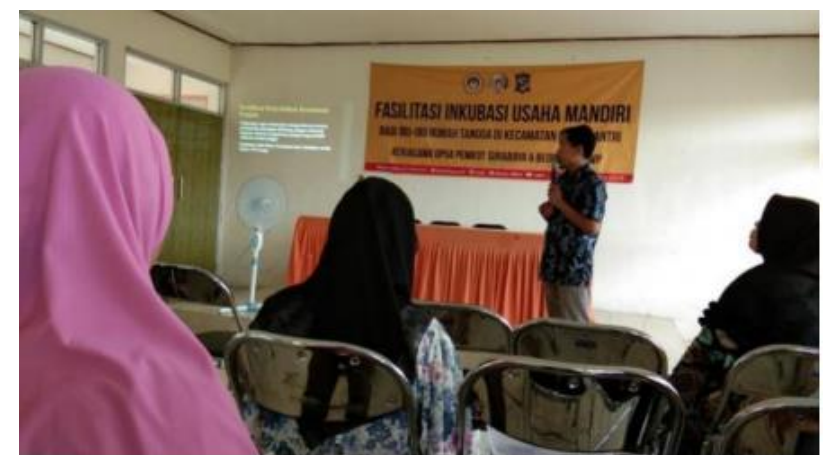

Gambar 8. Penyuluhan Legalitas dan Lingkungan Usaha oleh Andi Iswoyo, S.E, M.M.

\subsection{Penyuluhan Akses Permodalan}

Penyuluhan akses permodalan merupakan edukasi bagi peserta untuk mendapatkan permodalan dalam rangka pengembangan usaha. Pada umumnya, permasalahan yang dihadapi oleh Usaha Kecil dan Menengah (UKM) antara lain kurangnya permodalan dan terbatasnya akses pembiayaan (Kristiyanti, 2012). Oleh sebab itu, pada pelatihan ini para peserta diberi solusi termudah untuk mendapatkan modal dalam memulai sebuah usaha, salah satunya ialah dengan menyisihkan sekian rupiah setiap hari dari uang belanja.

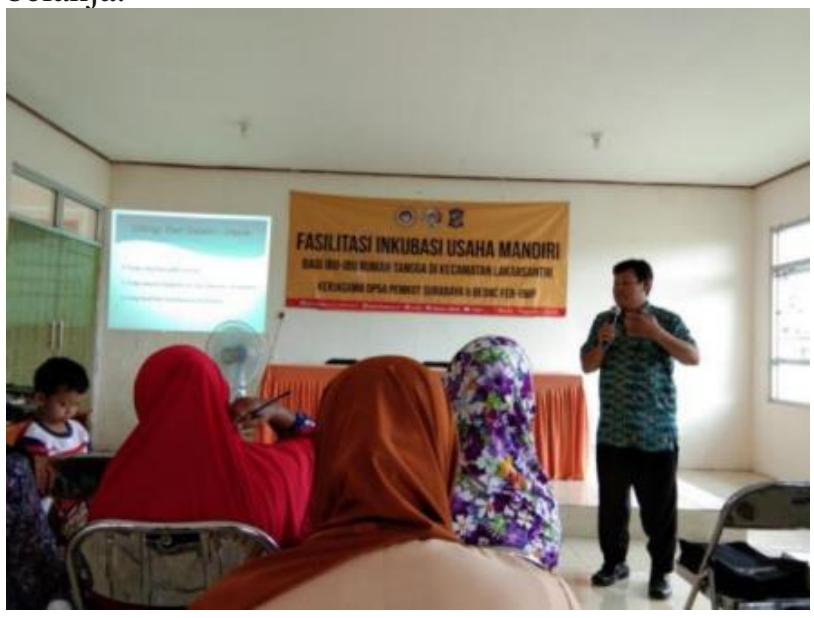

Gambar 9. Penyuluhan Akses Permodalan oleh Antoni, S.E., M.SA.

\section{8 Pendampingan Ketrampilan Produksi}

Pendampingan Ketrampilan Produksi merupakan waktu yang disediakan oleh narasumber untuk konsultasi terhadap permasalahanpermasalahan yang dihadapi oleh peserta saat melakukan proses produksi. Pada pendampingan Ekonomi, Sosial, dan Budaya 
ketrampilan produksi ini tim juga menilai apakah produk yang sudah diproduksi oleh peserta sudah layak jual atau belum.

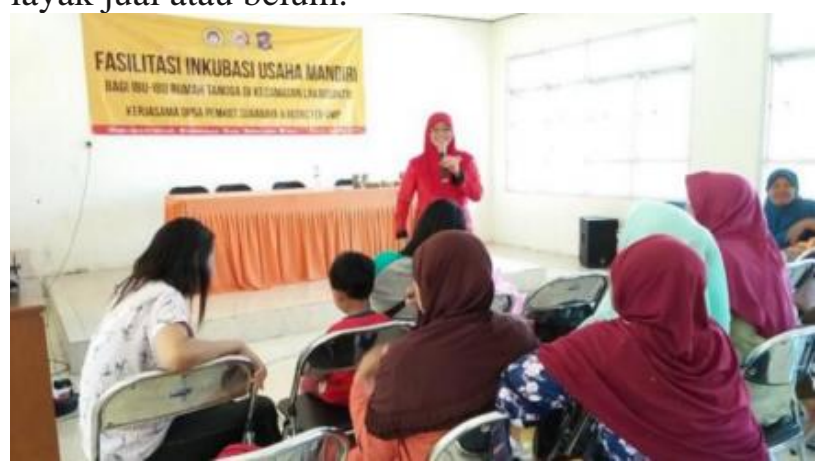

Gambar 10. Pendampingan Ketrampilan Produksi oleh Karlin, S.E., M.Ak. dan Tim

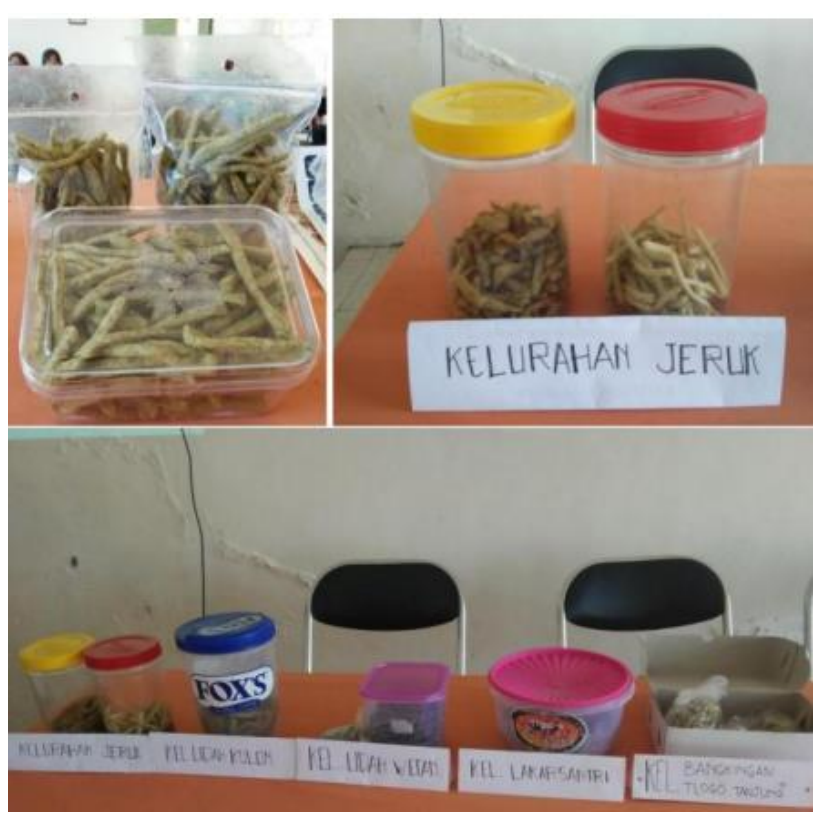

Gambar 11. Produk berupa Stick Semanggi yang sudah diproduksi oleh Peserta

\subsection{Pendampingan Manajemen Pemasaran}

Pendampingan manajemen pemasaran bertujuan untuk menampung permasalahan pemasaran yang telah dilakukan oleh peserta pelatihan. Narasumber pendampingan ini memberikan solusi terkait permasalahan tersebut. Bagi peserta yang penjualannnya sudah meningkat diberi kesempatan untuk berbagi pengalaman dalam melakukan penjualan produk sehingga dapat menjadi alternatif penyelesaian dari kendala pemasaran yang dihadapi peserta.

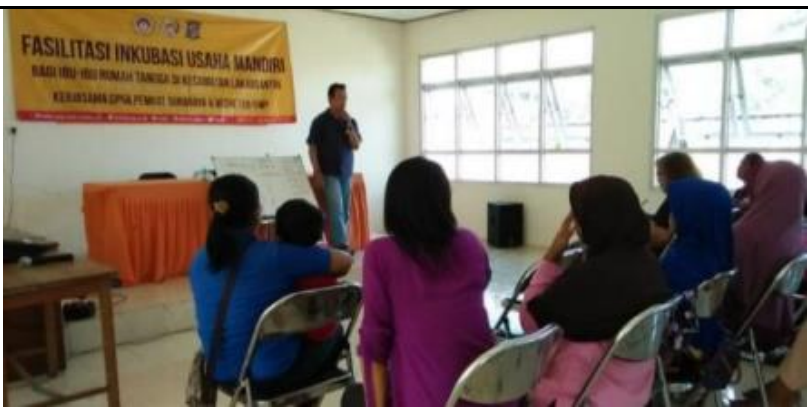

Gambar 12. Pendampingan Manajemen Pemasaran oleh Agung Bayu Murti, S.E, M.SE.

\section{10Pendampingan Manajemen Keuangan}

Pendampingan Manajemen Keuangan bertujuan untuk memberikan pengarahan secara langsung kepada peserta yang masih kesulitan dalam membuat pencatatan keuangan. Bagi peserta yang sudah mampu membuat pencatatan juga dikoreksi hasilnya agar tidak terjadi kesalahan.

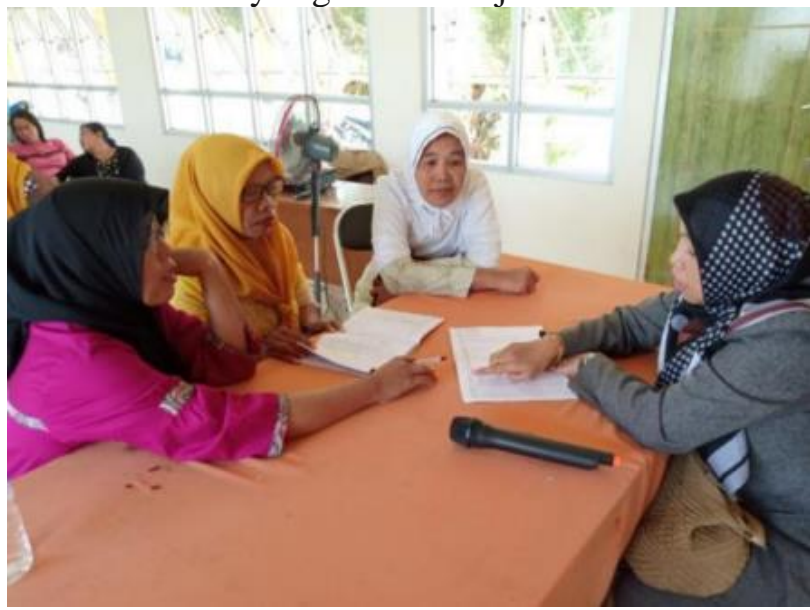

Gambar 13. Pendampingan Manajemen Keuangan oleh Aminatuzzuhro, S.E., M.Si.

\section{11 Pendampingan Manajemen SDM}

Pendampingan Manajemen Organisasi dan SDM ini bertujuan agar peserta menyampaikan keberhasilan maupun kendala yang dihadapi dalam menjalankan usaha secara kelompok maupun individu. Para narasumber perlu memastikan kemampuan peserta dalam menerapkan ilmu tentang Manajemen Organisasi dan SDM dalam kelompoknya masing-masing. 


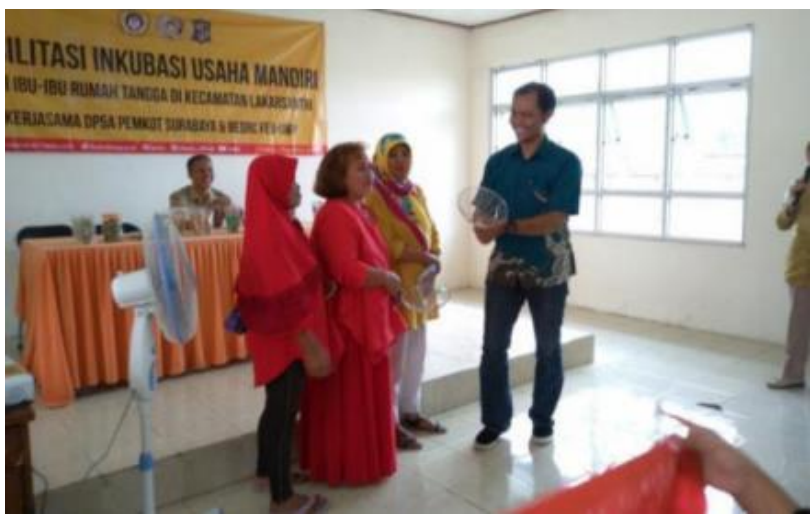

Gambar 14. Pendampingan Manajemen Organisasi dan SDM oleh Yanuar Fauzuddin, S.E, M.M.

\section{12 Pendampingan Legalitas Usaha}

Pendampingan Legalitas Usaha ini bertujuan untuk mendampingi peserta dalam proses mempersiapkan mengurus legalitas. Diantaranya peserta didampingi dalam hal pembuatan label produk. Narasumber memberikan saran-saran agar Label Produk peserta memenuhi kriteria yang telah ditentukan.

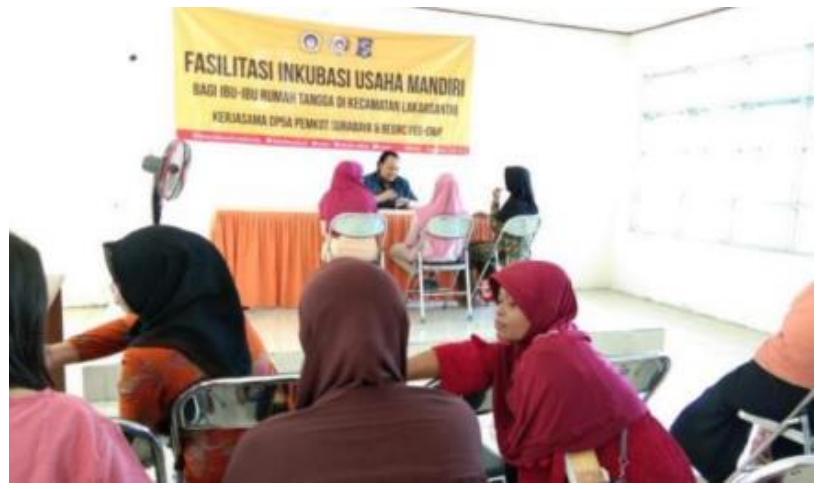

Gambar 15. Pendampingan Legalitas Usaha oleh Hendrik Rizqiawan, S.E, M.M.

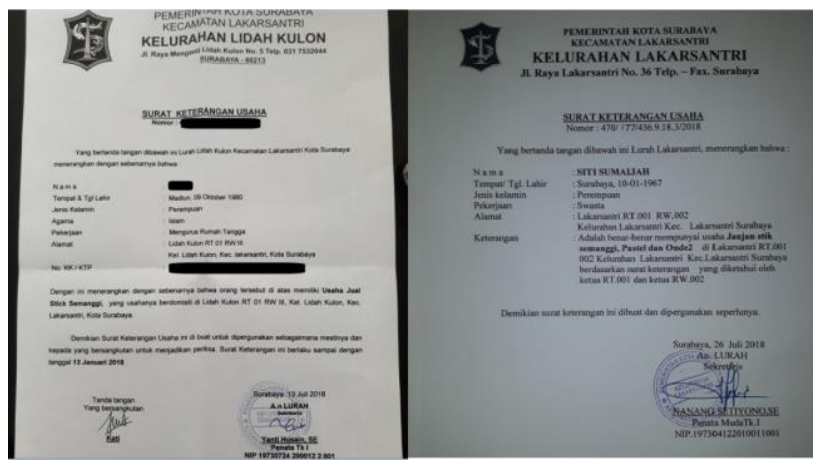

Gambar 16. Legalitas Usaha yang sudah diurus oleh Peserta

\section{KESIMPULAN}

Pemberdayaan ekonomi melalui kegiatan fasilitasi inkubasi usaha mandiri yang dilakukan di Kecamatan Lakarsantri Kota Surabaya ini menyimpulkan bahwa dalam program pemberdayaan ekonomi dibutuhkan pelatihan dan pendampingan yang tepat dan sesuai dengan kebutuhan peserta. Kegiatan pemberdayaan dengan karakteristik peserta tidak produktif dan tingkat ekonomi rendah membutuhkan pemberian materi motivasi yang intensif, baik ketika di ruang kelas maupun pendampingan dan di luar pertemuan formal. Produk yang dilatihkan hendaknya memiliki kemudahan dan biaya yang terjangkau dalam proses produksi, sehingga membuat peserta senantiasa aktif dalam praktek produksi mandiri. Produk dengan karakteristik cepat diproduksi dan cepat menghasilkan juga dapat meningkatkan antusiasme peserta dalam memulai wirausaha, karena perputaran uang yang cepat dapat memberikan kepuasan dalam menjalankan sebuah usaha dan berpengaruh pada tingkat motivasi peserta. Hal tersebut sejalan seperti yang dikemukakan oleh Yunal dan Indriyani (2013), bahwa motivasi memiliki pengaruh yang signifikan terhadap pertumbuhan sebuah usaha atau bisnis.

Fasilitasi inkubasi usaha mandiri ini juga terbukti berhasil dalam memberdayakan penduduk yang berstatus belum bekerja dan mengurus (ibu) rumah tangga dengan kondisi perekonomian yang kurang mampu, sehingga mereka lebih produktif. Hal tersebut terlihat dari produk stick semanggi yang dihasilkan dengan berbagai varian dan aktivitas usaha yang dijalankan oleh para peserta mulai dari proses produksi hingga pemasaran yang dapat dilihat pada gambar 17, 18 dan 19.

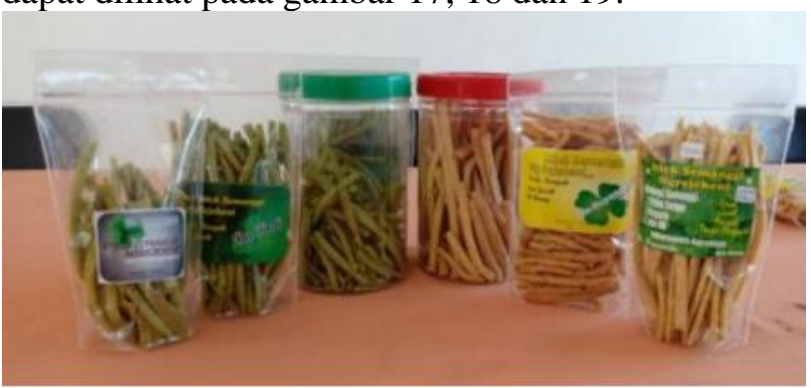

Gambar 17. Produk Hasil Produksi Peserta yang Dipasarkan 

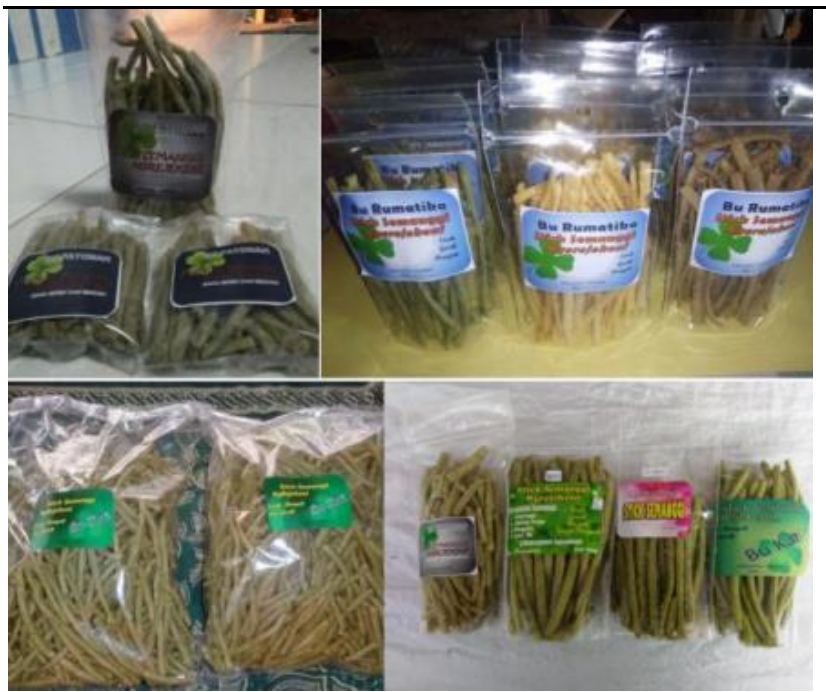

Gambar 18. Produk Hasil Produksi Peserta yang Dipasarkan

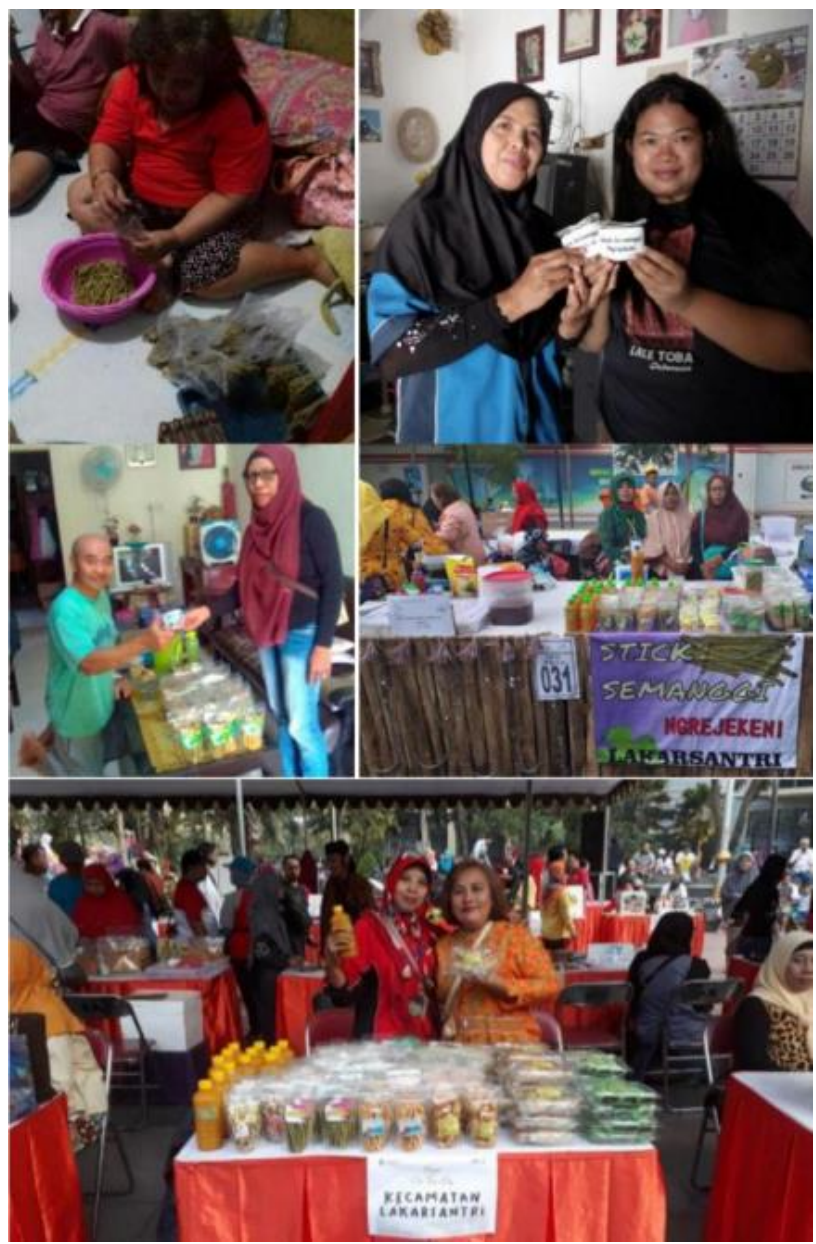

Gambar 19. Aktivitas Produksi dan Pemasaran yang dilakukan oleh Peserta
Para peserta juga dapat merasakan tambahan penghasilan dari usaha yang dijalankannya selama berlangsungnya program fasilitasi inkubasi usaha mandiri. Pada gambar 19 ada beberapa aktivitas pemasaran yang dilakukan peserta mulai dari ikut serta pameran, bazar hingga melayani pesanan. Bahkan salah satu perserta yaitu tim dari Kelurahan Lidah Kulon menerima pesanan hingga luar kota. Hingga berakhinya program, peserta terdiri dari 5 tim dengan jumlah 16 orang peserta. Tentunya walau program fasilitasi inkubasi usaha mandiri sudah berakhir, diharapkan mereka dapat terus melanjutkan usaha yang sudah dijalankan, baik tetap dengan format tim yang sama atau memulai usaha sendiri-sendiri. Sehingga jumlah usaha mikro dan kecil pada Kota Surabaya dapat bertambah dan dapat membantu dalam meningkatkan perekonomian Kota Surabaya.

\section{UCAPAN TERIMAKASIH}

Terima kasih yang sebesar-besarnya disampaikan kepada:

1. Dinas Pengendalian Penduduk, Pemberdayaan Perempuan dan Perlindungan Anak, Pemerintah (DP5A) Kota Surabaya;

2. Jajaran Pejabat dan Staf Kecamatan Lakarsantri Kota Surabaya;

3. Jajaran Pejabat dan Staf Kelurahan Lidah Kulon Kecamatan Lakarsantri Kota Surabaya;

4. Universitas Wijaya Putra Surabaya, khususnya Fakultas Ekonomi dan Bisnis (FEB);

5. PT. Talenta Sukses Indonesia (TSI).

\section{REFERENSI}

Atmaja, Hanung Eka \& Ratnawati, Shinta (2018). Pentingnya Manajemen Sumber Daya Manusia untuk Meningkatkan Usaha Kecil Menengah. Riset Ekonomi Manajemen. DOI: 10.31002/rn.v2i1.818

Atmoko, T. Prasetyo Hadi (2017). Peningkatan Higiene Sanitasi Sebagai Upaya Menjaga Kualitas Makanan Dan Kepuasan Pelanggan Di Rumah Makan Dhamar Palembang. Jurnal Khasanah Ilmu, Vol. 8 No. 1. ISSN : 20870086 (Print), 2655-5433 (Online).

Fitriani, Rini (2017). Aspek Hukum Ekonomi, Sosial, dan Budaya 1145 
Legalitas Perusahaan atau Badan Usaha dalam Kegiatan Bisnis. Jurnal Hukum Samudra Keadilan, Vol. 12 No. 1. ISSN : 2615-3416 (Print), 2615-7845 (Online).

Kasmir \& Jakfar (2012). Studi Kelayakan Bisnis Edisi Revisi. Jakarta: Prenadamedia Group.

Kristiyanti, Mariana (2012). Peran Strategis

Usaha Kecil Menengah (UKM) Dalam Pembangunan Nasional. Majalah Ilmiah INFORMATIKA, Vol. 3 No. 1.

Kurniawan, Ferry Duwi \& Fauziah, Luluk (2014). Pemberdayaan Usaha Mikro Kecil dan Menengah (UMKM) dalam Penanggulangan Kemiskinan. JKMP (Jurnal Kebijakan dan Manajemen Publik), Vol. 2 No. 2. ISSN : 2338$445 X$.

Nainggolan, Khairina dkk (2017). Peningkatan Pendapatan Daerah Berbasis Pada Usaha Mikro, Kecil, Dan Menengah. ARISTO (Social, Politic, Humaniora), Vol. 5 No. 2. ISSN : 2338-5162 (Print), 2527-8444 (Online).

Nurjanah dkk (2012). Aktivitas Antioksidan dan Komponen Bioaktif Semanggi Air (Marsilea
Crenata). AJIE : Asian Journal of Innovation and Entrepreneurship, Vol. 1 No. 3. e-ISSN : 24770574, p-ISSN : 2477-3824.

Pemerintah Kota Surabaya (2017). Rancangan Akhir RKPD Kota Surabaya Tahun 2018. http://bappeko.surabaya.go.id/informasipublik/item/54-rkpd-2018

Umasugi, Linda (2012). Pendekatan Dinamis dalam Pengembangan UKM di Kota Ternate. Jurnal Ilmiah agribisnis dan Perikanan (agrikan UMMU-Ternate), Vol. 5 Edisi 1. ISSN : 1979-6072 (Print), 2621-0193 (Online).

Wibowo, Dimas Hendika dkk (2015). Analisis Strategi Pemasaran untuk Meningkatkan Daya Saing UMKM (Studi pada Batik Diajeng Solo). Jurnal Administrasi Bisnis (JAB), Vol. 29 No.1.

Yunal, Vivin Oblivia \& Indriyani, Ratih (2013). Analisa Pengaruh Motivasi Berwirausaha dan Inovasi Produk terhadap Pertumbuhan Usaha Kerajinan Gerabah di Lombok Barat. Agora, Vol. 1 No. 1. 